\title{
Introducing the Special Issue: Interview with Swati Parashar about Women and Feminism in Global Politics
}

\author{
Swati Parashar ${ }^{1} \mathbb{D}$, Daria B. Kazarinova ${ }^{2} \square$ \\ ${ }^{1}$ University of Gothenburg, Gothenburg, Sweden \\ ${ }^{2}$ RUDN University, Moscow, Russian Federation \\ 凹kazarinova-db@rudn.ru
}

\begin{abstract}
Gender issues and feminist studies are rare in Russian Political Science. This gap is surprising given the increasing international recognition of women's rights, as well as growing interest in mainstreaming gender equality norms and removing key obstacles to women's advancement. This special issue addresses this gap by bringing together studies that use feminist optics to examine a variety of political spaces, including those where feminism has not yet become an ideological mainstream. Presenting the contributions and the core ideas that unite them, we discussed with Professor Swati Parashar non-Western feminisms and problematic legacies of Western feminisms. Guiding our conversation were questions such as: What is feminism today? What is feminist foreign policy and what is its potential? In what ways can gender equality quotas contribute to the political empowerment of women? How can international organizations encourage diversity in women's representations from the Global South?
\end{abstract}

Keywords: Feminism, gender studies, women representation, gender quotas, non-Western feminism, feminist theory of International Relations, Feminist foreign policy, Women, Peace and Security agenda, Russian feminism, power of silence

For citation: Parashar, S., \& Kazarinova, D.B. (2022). Introducing the special issue: Interview with Swati Parashar about women and feminism in global politics. RUDN Journal of Political Science, 24(1), 7-15. https://doi.org/10.22363/2313-1438-2022-24-1-7-15

\section{Женщины и феминизм в глобальной политике: интервью со Свати Парашар (вместо предисловия)}

\author{
С. Парашар ${ }^{1 \mathbb{D}, ~ Д . Б . ~ К а з а р и н о в а ~}{ }^{2} \mathbb{D} \square$ \\ ${ }^{1}$ Гётеборгский университет, Гётеборг, Швеция \\ ${ }^{2}$ Российский университет дружбы народов, Москва, Российская Федерация \\ 凹kazarinova-db@rudn.ru
}

\begin{abstract}
Аннотация. Гендерные проблемы и феминистские исследования редко встречаются в российской политической науке. Этот разрыв вызывает удивление, учитывая растущее международное признание прав женщин, а также растущий интерес к актуализации норм гендерного

(C) Parashar S., Kazarinova D.B., 2022

(c) (i) This work is licensed under a Creative Commons Attribution 4.0 International License https://creativecommons.org/licenses/by/4.0/
\end{abstract}


равенства и устранению основных препятствий на пути улучшения положения женщин. Данный специальный выпуск восполняет этот пробел, объединяя исследования, использующие феминистскую оптику для изучения различных политических пространств, в том числе тех, где феминизм еще не стал идеологическим мейнстримом. Представляя вклад и основные идеи, которые их объединяют, мы обсудили с профессором Свати Парашар незападный феминизм и проблемное наследие западного феминизма. Направлением нашего разговора были такие вопросы, как: Что такое феминизм сегодня? Что такое феминистская внешняя политика и каков ее потенциал? Каким образом квоты на гендерное равенство могут способствовать расширению политических прав и возможностей женщин? Как международные организации могут поощрять разнообразие в женском представительстве?

Ключевые слова: феминизм, гендерные исследования, женское политическое представительство, квоты, незападный феминизм, феминистская теория международных отношений, феминистская внешняя политика, повестка дня в области мира и безопасности для женщин, российский феминизм, сила молчания

Для цитирования: Parashar S., Kazarinova D.B. Introducing the special issue: Interview with Swati Parashar about women and feminism in global politics // Вестник Российского университета дружбы народов. Серия: Политология. 2022. Т. 24. № 1. С. 7-15. https://doi.org/10.22363/2313$1438-2022-24-1-7-15$

Today, the international recognition of women's rights is increasing and the interest in mainstreaming gender equality norms and removing key obstacles to women's advancement is growing. However, gender issues and feminist studies are rare in Russian Political Science. While Russian civil society is alive with diverse ideas of gender equality and feminisms, Russian Political Scientists pay little - if any - attention to gender(ed) politics and their intellectual contribution to the development of non-Western feminisms is minor.

The idea that the Soviet project solved the so-called "women's issue" together with the major feminist concerns prevails in both public and academic discussions. Many believe that Soviet women and, accordingly, women of post-Soviet Russia do not need to fight for political rights, demand access to education and labor market, protect women's reproductive rights, and do not encounter racialized problems. Indeed, the experiences of Russian women differ significantly from the experiences of women in the Global North or post-colonial societies of the Global South. Queer, body- and sex-positive, intersectional, and radical feminisms are far from the Russian mainstream and outside of the core political agenda. However, these feminist discourses attract young people and enter popular culture (especially via women's stand-up comedy). A brief survey of RUDN University students who took an elective course Feminism in politics and culture shows that we need to include gender issues and feminist theories in the curriculum. ${ }^{1}$

Today, Russian feminism challenges the discourse of "traditional values" promoted by the state, yet its discursive strategies do not merge with the Western

\footnotetext{
${ }^{1}$ Online survey N=59 among RUDN students: $81 \%$ female students, 70\% study humanities and social sciences, more than $51 \%$ consider gender and feminism issues important for themselves, more than $80 \%$ often or occasionally face the gender inequalities, more than $72 \%$ require more gender and feminist focus in their curriculum.
} 
agenda. These strategies focus on acute social problems of Russian society, including domestic violence, reproductive pressure, pay gap, restrictions for women's NGOs, and normalized sexism in all public spaces. However, only a few female politicians include these topics in their political programs. Those who risk doing so face rather harsh criticism from both their colleagues and the broad conservative community (Anna Volkova, Galina Lukyanova, and Tatiana Kulakova examine a case of gender-oriented digital vigilante communities). We decided to discuss key ideas of our special issue with Swati Parashar who is our editorial board member. She is also the current co-editor of the International Feminist Journal of Politics, co-editor of the recent "Routledge Handbook of Feminist Peace Research" [Väyrynen, Parashar et al. 2021] and other volumes [Parashar et al. 2018, Parpart, Parashar 2019], and is Professor in Peace and Development at the School of Global Studies, University of Gothenburg in Sweden.

- Does Russian feminism sound weird in the context of how Russia presents itself in the international arena, responding aggressively to "wokeism"?

- Russian feminism does not sound weird at all. In these times, feminism could be understood from two perspectives. The first aspect is the regime or state versions of feminism. Most past and current regimes have different connotations and understandings of the idea of feminism. They have different ways of interpreting what feminists do, how radical feminists act and how perhaps feminism destroys the basic traditional values of society. These regimes (in Turkey, Poland, Hungary, for example) in the name of preserving traditional values have taken tough measures against gender equality and gender justice, and the Russian regime has also led this backlash against progressive feminist values. Most of these regimes have their own ways of addressing gender roles and what men and women should do in their societies. Their backlash against feminism and gender studies cuts across different spheres of society, polity, academic institutions, and labor market conditions. Despite the regime backlash, Russian feminism has had an impact on present day gender discourse and practice in the country. The second point is the definition of the term, feminism. Feminism is not a popular word and most communities, societies and states define it to suit their agenda. The terminology has generated debate in different parts of the world as to what constitutes feminism and how it should shape the gender discourse. This is an unresolved issue. Several societies use feminist approaches to address various aspects of women's rights and gender equality, including human rights, abortion control, social reforms, women's education, and women's right to owning properties. All these might deploy feminist thinking and approaches, but there may be resistance to defining it as such. Feminism must be understood within specific historical contexts, challenging traditional discriminatory norms against women and other minorities. In this sense, we must appreciate the achievements of Russian feminism, that has both challenged

2 Lukin A.V. The Right to Insanity: A New Ideology of "Woke" Western Elites and Its Consequences. URL: https://eng.globalaffairs.ru/articles/the-right-to-insanity/ (accessed: 28.12.2021). 
the backlash from various regimes and worked for the advancement of women's rights in the country.

Anna Kuteleva, who inspired the theme of this issue, stresses that oppressive relations that feminists oppose have different configurations depending on the social, economic, cultural, and political contexts. As a result, the monolithic notion of feminism crumbles into multiple feminisms. She analyzes the conceptual and political rifts within the "global" feminism associated with the hegemony of "western" ideas and its criticism by transnational and postcolonial feminists. Examining more than a million Twitter posts by the fourth-wave feminists, Anna Gnedash demonstrates that their discourses are mosaic and fluid, sliding on the surface of everyday life.

- If today's feminism is as heterogeneous and diverse as our authors claim, is there global feminism? Do Western and non-Western feminists have a shared agenda? A common methodology? Or no more than a set of the very basic ideas in the context of human rights?

- Feminism has come in different waves. These waves also highlighted the differences between Western and non-Western feminism. Overall, there is a disconnect between global North and South, due to particular understandings of the terminology and different historical trajectories and socio-political developments. There has always been some finger pointing towards certain places specifically Africa, Middle-East, Asia etc. which are seen as not doing feminism the right (read Western) way. The recent Black Lives Matter movement also highlighted the angst of black feminists who once again highlighted the brutalities of colonialism and how white feminists were complicit. However, in recent times, there have also been a lot of dialogue and discussions between feminists from the Global South and North and a transnational feminist network has emerged. Feminists in several countries and community organizations are working together to challenge regimes, institutions and societies against sexism, racism, gender-based violence etc. There are many transnational conversations taking place beyond statist discourses but it can certainly be better. First, there should be constant cooperation and dialogue among feminists within the regions and countries in terms of advocating for similar issues and providing support in their quest to find solutions. These can be done through stakeholder meetings and conferences, building transnational networks to project feminist ideas. Many of the issues are common to both western and nonwestern feminists e.g. labor rights, sexual violence, domestic violence, reproductive rights, political representation, other forms of gender discrimination etc.

Also, there should be a reconsideration of the indiscriminate use of the vocabulary of feminism, to focus on all aspects of women's rights and issues in different forms. This pragmatic change will seek to redefine the course of gender activism and enable feminism without its limiting language and vocabulary.

Valentina Uspenskaya and Nataliya Kozlova conceptualize feminist foreign policy. They analyze the so-called "Hillary doctrine" and the UN feminist resolutions, linking these initiatives to the theory and practice of international relations. Hussein Abbasov, in contrast, focuses on the fundamental limitations of 
the landmark UN Security Council Resolution 1325 on women, peace, and security and brings to the fore its failure to achieve the goals lobbied by women rights experts, scholars, and international diplomats. His study unveils the pragmatic approach of the global political elite in addressing gender justice issues based on rationality and patriarchy.

- Handbook of Feminist Peace Research that you recently co-edited [Väyrynen, Parashar et al. 2021] argues that critical feminist thinking is necessary to analyze the core issues of peace and conflict and is fundamental to finding solutions for global problems. At the international level, is feminist foreign policy an empty political rhetoric or a road map to implementing critical thinking? Can it gain momentum in the post-pandemic world? And, finally, what are the relations between feminist foreign policy and hypermasculine conservative foreign policy of authoritarian and populist leaders?

- That's a very good question. I've always been very critical of feminist foreign policy (FFP). So, if you are looking for a person who supports it, I'm not that person. I'm critical of two things: feminist foreign policy and what is called the Women Peace and Security agenda, emerging out of UN Resolution 1325. My first point is that it has become a very instrumentalized way for western feminism to assert itself and project a very liberal, white, western agenda. I think most of feminist foreign policy or what Canada launched as "feminist foreign aid" or the Women Peace and Security agenda, benefited western feminists who got large grants from governments, and establish research centers and organizations. But actual work on the ground tells a different story. Moreover, these feminist centers work closely with states. Isn't that a problem, when feminists have had a very problematic and nuanced relationship with the state?

Secondly, most of this terminology that has evolved like feminist foreign policy assumes something new is being offered, pioneered by the West. Many of the countries in the Global South have had feminist foreign policy from time to time. They may not have used the term feminist foreign policy but they were feminist in how they approached things. I wrote a piece with my colleague Bina D'Costa on what FFP has meant in South Asia. At various points of time many governments in non-western context have taken very humanitarian positions which may look like FFP in action. So, it is not unique to Sweden or western democracies. These days one person who is often cited is Jacinda Ardern of New Zealand. I don't think these are unique countries. I think many countries have dealt with humanitarian and humane foreign policies.

My third point is that there is a certain coloniality in how FFP is framed. The very idea that some parts of the world can be told how to do feminism, how to think about feminist foreign policy is problematic. There is a civilizational mission here, whether or not you agree. If you look at some of the documents that are produced or some of the discourses around FFP, Women, Peace and Security (WPS) agenda, many training programs are undertaken in the Global South, Asia or Africa.

My fourth point that all these concepts: feminist foreign policy, feminist foreign aid, and the WPS agenda work around the idea of gender equality. What their 
advocates say is that they promote gender equality. As I understand and argue, it is very problematic to assume that societies that are non-western do not have a very enlightened sense of gender equality. If you look at some recent discourses in western feminism, they have developed tools to identify gender equality. But my point is can you really quantify this term and make it comparable without really paying attention to context and history.

We have to think about context, how these countries have evolved into modern nation states and what their histories are. In fact, many of the conservative laws in India which feminists have challenged were established during the colonial era. One such colonial law was section 377 of the Indian penal code which criminalized homosexuality. In 2018, it was declared unconstitutional by a bench of Supreme Court judges, after several decades of feminist and LGBTQ activism, but this law had its origins during the British colonial rule.

I want to address the last point. I wouldn't say that masculine illiberal regimes exist in a vacuum. In foreign policy even these regimes can show nuance. Foreign policy is a very complex domain. For example, India currently has in the international sense, an illiberal right-wing regime, which emphasizes on traditional values and talks about invoking the great Indian civilizational values. But if you study carefully, there is a continuity in foreign policy in the last 74 years since its independence, despite regime changes. In international relations you cannot act alone. Even conservative regimes like Saudi Arabia reinvent their foreign policy from time to time and show the world that they are trying to reform. So regimes can be illiberal but very careful when they craft foreign policy. Donald Trump, when he came to power, made ridiculous policies to stop refugees and vulnerable people from entering America. He introduced the Muslim ban but it was not sustainable. I think that political wisdom prevails in some form in most cases. Feminist foreign policy is very problematic in how it has been framed, understood and advocated.

- That was really my problem with the concept "Feminist foreign policy", it is a kind of analogue of Kantian idea of democratic peace. But the truth is democracies do fight and this idea fails. The idea of feminist peace also fails. But this idea of feminist peace is still enormously widespread. Why?

- Of course democratic peace theory has failed. Western democracies do not make war because they are busy bombing other parts of the world. Look at US, UK, France and what they do. Sweden is also known to sell arms to other countries. I agree with you. This idea that women should go into politics and make the world more peaceful does not help, it is not women's job to fix a world messed up by patriarchy. We want more women in politics because we want diversity of opinion and actions and we are tired of watching men usurp power all the time. Women are creative, have different ideas and thoughts even if they prefer to go to war. In India, we had a woman prime-minister, Indira Gandhi, who also went to war, but she had a very different approach to the politics of war. Same is the case with other women leaders, they bring fresh perspectives, and may not be necessarily peaceful. Look at Sheikh Hasina, Jacinda Ardern or Angela Merkel, or Late Benazir Bhutto in the past. There is no good enough reason to keep $50 \%$ of the population out of power. 
You cannot argue that as a woman should only enter politics if you work for women and world peace. That is an avoidable gender stereotype.

Anna Maria Leenders studies the roles modern international organizations play in women's right protection in the context of technological modernization. Particularly, she highlights the gender gap in using ICT technologies and concludes that the UN's sustainable development goals underestimate the importance of digitalization for ensuring women's rights, yet this initial inequality of access exacerbates the future inequalities.

Natalya Kolesnik demonstrates that more feminized regional governments are formed in economically prosperous regions of Russia, whereas gender imbalances often characterize the governments of regions that economically dependent on the central authorities and those located in the south of Russia. Her study supports the claim that economic backwardness, social conservatism, and women underrepresentation are interconnected. Irina Amiantova and Nikoloz Bitsadze study gender quotas for political participation in Georgia and conclude about their positive relationship.

- The rise of women representation in politics does not mean automatically a feminist politics. In conservative societies women tend to support conservative values as we see in multiple cases. When quantity of women participation turns into quality? Does the quotas really solves a problem?

- In India we have been asking for 33\% reservations for women in the Parliament, but we have not succeeded. I actually favor quotas and think that this is the way to make space for disadvantaged people and bring them to the mainstream, whatever that is. Women have been disadvantaged for far too long. Critics of quota always argue that it only empowers certain kind of women, it doesn't benefit the right kind of women. But the real problem is that sections of the population have been excluded, and it is important that these people get more visibility. This is the argument I make when I say that we need more women leaders, more women in politics and it does mean a more peaceful world. Having a woman prime-minister or a president in Russia will not mean that Russia will become less masculinist. Women leaders can also be brutal. But it doesn't mean that we do not make space for women leaders just because they are not doing the job that we think they should. The responsibility of making the world better does not lie with women or feminists. They are here to argue that we need a gender equal and gender just world. In my work on women militants, for example, I have argued that women have equal stake in violence and we should listen to violent women, not considering them aberrations and cogs in the patriarchal machine. I'm not saying that violence is a good thing. But why are violent women excluded?

In India we have quotas for castes minorities, for religious minorities, for indigenous minorities. I think quotas or positive discrimination really helps. The problem appears when these quotas become institutionalized and they don't allow real democratic values to emerge. Quotas become so entrenched in the structures that only some kind of people benefit on a repeat mode. In India one kind of analysis posits that quotas enable a creamy layer among the disadvantaged. The same 
families benefit from one generation to another, the rest are excluded. Social mobility is thus, restricted to only a few and their kin. Quotas have to be introduced but we need a detailed study and analysis of what they achieve in different contexts. I support quotas.

Liubov Prokopenko, as well as Valeria Utkina and Alina Efimova focus on women political participation in Africa. These studies show that women who choose a career in public administration still face gender discrimination and harassment.

- You worked in Africa and published an excellent paper in "Third World Quarterly" [Parashar, Schulz 2021]. What is African feminism about? Do western feminist movements help African women? What are the key challenges for UN empowerment programs?

- There is a lot of critique of western feminists and western governments development involvement in Africa. I live in Sweden which, like other Nordic countries, provides a lot of development aid to Africa. However, what this aid actually means on the ground needs to be independently evaluated. African feminists have always challenged the assumption that Africa does not have a strong feminist rights movement. They have argued that development aid is not charity given the exploitative histories of colonialism. Feminists of color, and African and African-American feminists in particular have spoken out against patronizing and appropriating tendencies of white western feminism.

Has western feminism collaborated well with African women? I would say, yes and no. Yes, because some development projects have been useful and relevant. There were a lot of development interventions in conflict societies and the resources come from the West. Africa is in need of resources, but African countries are not poor as a matter of choice and destiny. They were deliberately impoverished because of the histories of colonialism. Western counties went in and really devastated and pillaged Africa. Some UN agencies like UNICEF, UNDP, UNHCR do a lot of good work and they have an international staff. But the UN system is largely western dominated with western trained staff and volunteers who may not be trained in local contexts.

African feminists are resisting and have always resisted western development interventions that do not consider local contexts, are embedded in coloniality and ignore African aspirations and visons. And it is once again time for western feminists and western development interventions to actually listen to Africans. It is no longer the time for western feminists to talk and make African, Asian and Russian feminists listen, it should be the opposite.

- One of your latest volumes edited with your co-author is "Rethinking Silence, Voice and Agency in Contested Gendered Terrains". Could you explain more the concept of Power of Silence in this context, I am not familiar at all. It sounds really new.

- This is still a new idea. It comes from partly the critique of white western feminism which has insisted that resistance has to be vocal. You have to always perform speech acts to resist. Jane Parpart (Canadian IR feminist) and I argue that 
very often we underrate silence [Parpart, Parashar 2020]. It is wrong to assume that people who are silent are not resisting, they have no ideas, self-awareness or consciousness, they are just silently suffering. We challenge the idea that silence disempowers people. Silence can be a collective strategy of survival for many societies, and it can also be powerful and challenge oppressions. There are multiple ways where you can use silence to challenge oppressive structures and regimes. It can be symbolically deployed as well. Mahatma Gandhi remained silent one day a week; he called it silent fast. Silence also enables better listening. Not everyone can protest verbally and become vocal opponents. The book shows how silence can be creative in multiple ways, how it can allow you to go deep inside you, how it is liberating, personally evolutionary and meditative, when you can find internal power and courage to challenge any form of oppression.

The interview is presented by Daria Kazarinova Интервью подготовила Казаринова Дарья Борисовна

Received / Поступила в редакцию: 30.12.2021

Accepted / Принята к публикации: 30.12.2021

\section{References}

Parashar, S., \& Schulz, M. (2021). Colonial legacies, postcolonial 'selfhood' and the (un)doing of Africa. Third World Quarterly, 42(5), 867-881. https://doi.org/10.1080/01436597.2021.1903313

Parashar, S., Tickner, J.A., True, J., \& Spike Peterson, V. (Eds.). (2018). Revisiting Gendered States. Feminist Imaginings of the State in International Relations. Oxford University Press.

Parpart, J.L., \& Parashar, S. (Eds.). (2020). Rethinking Silence, Voice and Agency in Contested Gendered Terrains. Routledge.

Väyrynen, T., Parashar, S., Féron, E., \& Confortini, C.C. (Eds.). (2021). Routledge Handbook of Feminist Peace Research. Routledge.

\section{About the authors:}

Swati Parashar - PhD in Politics and International Relations, Professor in Peace and Development School of Global Studies, University of Gothenburg (Gothenburg, Sweden) (e-mail: swati.parashar@gu.se) (ORCID: 0000-0001-7162-6367)

Daria B. Kazarinova - PhD in Political Science, Associate Professor of the Department of Comparative Politics, Peoples Friendship University of Russia (RUDN University) (Russian Federation) (e-mail: kazarinova-db@rudn.ru) (ORCID: 0000-0002-9416-5898)

\section{Сведения об авторах:}

Парашар Свати - доктор политических наук (политика и международные отношения), профессор в области мира и развития Факультета глобальных исследований Университета Гётеборга (Гётеборг, Швеция) (e-mail: swati.parashar@gu.se) (ORCID: 0000-0001-7162-6367)

Казаринова Дарья Борисовна - кандидат политических наук, доцент кафедры сравнительной политологии Российского университета дружбы народов (e-mail: kazarinova-db@rudn.ru) (ORCID: 0000-0002-9416-5898) 